\title{
Цигулка, гъдулка... i inne nazwy 'skrzypiec' w języku bułgarskim (w porównaniu z pozostałymi językami słowiańskimi)
}

Muzyka w starożytności oznaczała wszelką sztukę i naukę będącą pod opieką muz. Później - w średniowieczu - znaczenie tego terminu ograniczono wyłącznie do sztuki pięknej, której materiałem są dźwięki i inne odgłosy wydobywane przez głos ludzki i różnego rodzaju instrumenty muzyczne, posiadające określoną wysokość, barwę, głośność, czas trwania, sposób wykonania, następujące po sobie pojedynczo lub we współbrzmieniach w myśl pewnej prawidłowości melodyki, harmonii i kontrapunktu, ujęte w prawidłowość metro-rytmiczną i określoną całość formalną, zgodnie z wymaganiami estetyki. Muzykę dzielimy na poważną (koncertową, symfoniczną, kameralną, solistyczną, operową itp.) i lekką (rozrywkową: piosenkarską, taneczną, operetkową). Dalszy podział pokrywa się z systematyką form muzycznych.

Istotny jest również podział na muzykę wokalną (śpiew) i instrumentalną (wykonywaną na wszelkiego rodzaju instrumentach muzycznych). Wyróżniamy także muzykę wokalno-instrumentalną (głos z towarzyszeniem instrumentalnym).

Podstawą podziału instrumentów muzycznych jest rodzaj źródła dźwięku. Stąd też wyróżniamy instrumenty strunowe (chordofony), gdzie źródłem dźwięku jest drgająca struna, instrumenty dęte, inaczej aerofony (źródłem dźwięku jest drgający słup powietrza), instrumenty perkusyjne (dzielą się na membranofony, w których źródłem dźwięku jest uderzona membrana, 
oraz idiofony, w których dźwięk powstaje przez drganie całego instrumentu), a w czasach współczesnych także instrumenty elektroniczne.

Chordofony ulegają dalszemu podziałowi ze względu na sposób wydobywania dźwięku na instrumenty smyczkowe (współczesne: skrzypce, altówka, wiolonczela, kontrabas; historyczne: tenorki i rozmaite viole, np. viola de amore, viola de gamba), szarpane (np. gitara, mandolina, lutnia, cytra, harfa, banjo, także klawesyn) i uderzane (fortepian / pianino, cymbały). Fortepian / pianino i klawesyn nieraz klasyfikuje się jako instrumenty strunowe klawiszowe.

O muzyce dawnych Słowian wiele napisano m.in. w Słowniku starożytności słowiańskich (s.v. Muzyka u Słowian). Opis od razu jest powiązany z podziałem na kraje, przy czym pierwsza jest opisana Bułgaria. Z uwagi na objętość artykułu nie wnikam w szczegóły, niemniej jednak trzeba zauważyć, iż zamieszczono tam pewne nazwy instrumentów: m.in. гайда 'dudy', кавал 'owczarski flet podłużny, fujarka pasterska', гъдулка (zwana także гусла) 'instrument smyczkowy, ludowe skrzypce' i bębenek ${ }^{1}$.

Terminologią muzyczną w językach słowiańskich interesowało się niewielu uczonych. Napisano nieliczne monografie, np. B. Szydłowskiej-Ceglowej, pt. Staropolskie nazewnictwo instrumentów muzycznych (Wrocław 1977), czy też M. Aumayr, Untersuchungen an Bezeichnungen von Musikinstrumenten in der russischen Sprache (Wien 1985). Jedną z ważniejszych prac jest artykuł Wiesława Borysia pt. Kultura muzyczna dawnych Słowian w świetle leksyki $i^{2}$, który zawiera wiele informacji o dawnych (prasłowiańskich) nazwach instrumentów muzycznych i o ogólnej terminologii muzycznej.

Tematem niniejszego artykułu są nazwy 'skrzypiec’ w języku bułgarskim, przedstawione na tle słowiańskim.

Skrzypce z uwagi na duże możliwości kolorystyczne, artykulacyjne i dynamiczne są jednym z najważniejszych instrumentów solowych a także (w zwielokrotnionej obsadzie) stanowią one najważniejszy instrument orkiestry symfonicznej oraz zespołów kameralnych. Instrument ten powstał w okresie renesansu (XVI w.) we Włoszech, chociaż są informacje o jego obecności w Polsce już w II poł. XV wieku (pierwotnie pod nazwą skrzypice) ${ }^{3}$.

1 Słownik starożytności słowiańskich. Encyklopedyczny zarys kultury Słowian od czasów najdawniejszych do schyłku XII wieku, t. III, cz. I, Wrocław - Warszawa - Kraków 1967, s. 331-334.

${ }^{2}$ W. Bor yś, Kultura muzyczna dawnych Słowian w świetle leksyki, [w:] Dzieje Słowian $w$ świetle leksyki, red. W. B oryś, J. Ru sek, Kraków 2002, s. 83-94.

3 Zob. Wielka encyklopedia powszechna, t. X, Warszawa 1967, s. 578. Wiesław Boryś w Słowniku etymologicznym języka polskiego (B oryś SE), wymienia wyrazy skrzypica i skrzypice 'strunowy instrument muzyczny, może lutnia czy skrzypce'. 
Jest to instrument o najwyższej skali z grupy smyczkowych, czterostrunowy o stroju g (196Hz), d ${ }^{1}(293,7 \mathrm{~Hz}), a^{1}(440 \mathrm{~Hz}), \mathrm{e}^{2}$ (659,3 Hz), umożliwiający osiągnięcie skali ponad czterech oktaw - od g $(196 \mathrm{~Hz})$ nawet do c $c^{5}(4184 \mathrm{~Hz})$.

Podstawową nazwą 'skrzypiec' w języku bułgarskim jest u̧игулкa. Słownik współczesnego bułgarskiego języka literackiego pod red. S. Romanskiego ${ }^{4}$ dokumentuje ten wyraz, tłumacząc jego znaczenie następująco: 'четириструнен лъков инструмент с висок тембър' - pol. 'czterostrunowy instrument smyczkowy o wysokiej skali'. Ilustruje go kilkoma przykładami: Мудно отстрана цигулка пробуча и србчно сви, На механата засвириха ициулки, Настройвам изгулка (i in.). Wymienia też frazeologizm (zwrot) Свиря първа цицгулка (książk.) 'играя главна, съществена роля в нещо' - pol. 'odgrywać w czymś główną, istotną rolę'. Frazeologizm ten ma dokładny odpowiednik w języku polskim grać pierwsze skrzypce (o tymże znaczeniu) a także w innych językach słowiańskich, co zostanie zasygnalizowane w dalszej części artykułu. Słownik ten również odnotowuje derywaty, utworzone od interesującego nas rzeczownika: цицулар 'музикант, който свири на цигулка' - pol. 'muzyk grający na skrzypcach', ilustrując go przykładem (przysłowiem): цицулар къща не храни; ицгуларка 'жена цигулар' (pol. 'skrzypaczka'), bez przykładów a także przymiotnik цицгулков 'skrzypcowy', ilustrując go dwoma przykładami: цзигулков концерт, цигулкова продукция. Български тълковен речник (BTR $)^{5}$ także odnotowuje interesującą nas nazwę, definiując ją tak samo, jak RSBKE. Derywat цицгулар tłumaczy przez synonimiczny rzeczownik виолонист, ilustrując go tym samym przysłowiem. Wymienia też przymiotnik изигуларски 'който се отнася на цигулар' - pol. 'dotyczący skrzypka', ilustrując go przykładem: изигуларски живот. BTR także zamieszcza interiekcję uъигу-мигу oznaczającą grę na skrzypcach ('означава свирене на цигулка или гъдулка') - ten ostatni rzeczownik oznacza 'ludowe, prymitywne skrzypce'.

Słownik języka bułgarskiego Najdena Gerowa ${ }^{6}$ tłumaczy wyraz цицу̀лкa następująco: 'направа със струны за свиренє с лпка'. Podaje sporo synonimów: гънилка, гъдулка, кемене, лаута, виулець i rosyjski odpowiednik скрипка. Dokumentuje też deminutivum цицуулчица a także inne derywaty oraz interiekсје̨ чигу-ицгу (oznacza grę na skrzypcach). Ilustruje ją przykładem: Чигy-uцигy, дъдо веле, дай ми какљ лулп! Цигу-мигу на три дни, оле мале за вси дни!

Przyjrzyjmy się teraz budowie słowotwórczej interesującego nas wyrazu. Słownik słowotwórczy języka bułgarskiego traktuje rzeczownik цъцулка jako

4 Речник на съвременния български книжовен език, t. I-III, София 1955-1959 (RSBKE).

5 Л. Андрейчин i in., Български тълковен речник, София 1955 (BTR).

${ }^{6}$ Н. Геров, Речникъ на българский языкъ, t. I-V, Пловдив 1895-1904 (Gerow). 
wyraz niemotywowany (wymienia derywaty: цигулков, цигулар oraz derywaty od tego ostatniego: ццигуларка, цигуларство). Tak jest ze współczesnego punktu widzenia. Jednakże etymologicznie jest on derywatem (zleksykalizowanym), albowiem daje się w nim wyodrębnić przyrostek -улкa. Jest to formant tworzący nazwy przedmiotów, zwykle od podstaw czasownikowych. Występuje on w takich wyrazach jak: гъдулка, дрънкулка, висулка, шушулка ${ }^{7}$ (pierwszy z nich jest także nazwą 'ludowych skrzypiec'). Podstawą słowotwórczą jest więc dźwiękonaśladowcze u̧uz-, występujące m.in. w interiekcji u̧uzy-миนгy. Daje się to łatwo uzasadnić tym, że w innych językach słowiańskich (np. w polskim, rosyjskim, ukraińskim, białoruskim) nazwy tego instrumentu pochodzą od wyrazów dźwiękonaśladowczych, np. pol. skrzypce < skrzypieć 'wydawać charakterystyczny głos, skrzypienie' (por. także ros. i ukr. скрùnкa, brus. скрыпка), a poza tym w języku bułgarskim jest też wyraz гъдулка oznaczający 'ludowy instrument smyczkowy z 3-5 strunami, rodzaj prymitywnych skrzypiec, gęśle, pochodzący od rdzenia dźwiękonaśladowczego ( $2 ъ \partial<$ ps. ${ }^{\star} g Q d \succsim$ 'brzęczeć). Za dźwiękonaśladowczym pochodzeniem wyrazu uนuгyлкa opowiada się też Stefan Mładenow ${ }^{8}$. Od rdzenia ц̧иг- pochodzi też czasownik цзигувам 'свиря на цигулка' - pol. 'grać na skrzypcach' (notowany tylko przez słownik Gerowa). Utworzony został od rdzenia dźwiękonaśladowczego za pomocą przyrostka $-y b a$, tworzącego czasowniki niedokonane, wielokrotne. Słownik ten notuje też utworzone od niego nomen deverbale uциуване. Pewne problemy słowotwórcze stwarza rzeczownik ццигулар 'skrzypek'. Słownik słowotwórczy języka bułgarskiego wskazuje, iż jest on bezpośrednio motywowany rzeczownikiem цигулка. Jest on derywowany za pomocą przyrostka -ap, tworzącego nomina agentis. Wskazuje to na hipotetyczną obecność augmentativum ųигула, formy derywowanej od rdzenia onomatopeicznego uциг-za pomocą przyrostka -ула - formantu ekspresywnego, tworzącego najczęściej augmentativa (przyrostek ten nie jest charakterystyczny dla bułgarskiego języka literackiego) ${ }^{9}$. Należy

7 Zob. Граматика на съвременния български книжовен език, t. 2: Морфология, София 1983, s. 59.

8 Zob. Ст. Младенов, Етимологичен и правописен речник на бблгарския книжовен език, София 1941, s. 676.

${ }^{9}$ Граматика... (ор. cit.) nie wymienia przyrostka -yла w ogóle. Franciszek Sławski wymienia przyrostek -ula // -ula, przy czym zaznacza, iż nie występuje on w wyrazach prasłowiańskich oraz, że w poszczególnych językach słowiańskich spotyka się go najczęściej w funkcji formantu ekspresywnego, tworzącego zwykle augmentativa (ew. pejoratywne nomina agentis). Przykładem może być pol. piguła zam. pigułka. Może on też oznaczać deminutiva i hipocoristica (zob. F. Sławski, Zarys słowotwórstwa prasłowiańskiego, [w:] tego ż, Słownik prasłowiański, t. I, Wrocław 1974, s. 110-111). 
też wziąć pod uwagę fakt, iż przyrostek -yлкa jest z pochodzenia formantem złożonym, powstałym z kontaminacji morfemów -ula- + bka, stąd też nomen agentis цицглар utworzone jest od postaci ццигула, bez rozszerzenia o sufiks - $\kappa$ tworzący m.in. deminutiva. Od tegoż tematu utworzone jest deminutivum ицигулиица (za pomocą przyrostka -чица) ${ }^{10}$.

Inną nazwą 'skrzypiec' w języku bułgarskim jest гъдулка. Słownik języka bułgarskiego BAN tłumaczy wyraz гъдулка następująco: 'народен лъков музикален инструмент с три или четири струни, направен от цял къс дърво, с тяло във форма на надлъжно прерязана круша и шийка, завършаща с главичка' - pol. 'ludowy instrument muzyczny smyczkowy trzy- lub czterostrunowy, wykonany z jednego kawałka drewna, o korpusie w kształcie przekrojonej gruszki z szyjką i główką. Definicja ta wskazuje na to, że wyraz ten oznacza prymitywne, ludowe skrzypce, własnoręcznie wystrugane (np. z gonta); gęśle (ang. fiddle). Słownik ten ilustruje omawiany wyraz wieloma przykładami. Oto niektóre: Имах една орехова гъдулка. Свирех с нея на хората, веселях им съриата; Едни от най-разпространените народни музикални инструменти у нас са гъдулка, кавальт и гайдата (RBE, 3). Słownik ten wymienia też liczne derywaty: гъдулчица 'dem. od гъдулка' (budowa słowotwórcza jak ц̧игулчица), гъдулар 'mężczyzna grający na prymitywnych ludowych skrzypcach, gęślach' (budowa słowotwórcza jak uицглар). Wyraz ten został zilustrowany przykładami: На mрапезата един гъдулар подкара старовремска песен ..., Той беше селски гъдулар и идеше в Търново по Великден, та ходеше да свири по къщята (RBE, 3). Wymienia też inne derywaty, jak np. гъдуларин (synonim wyrazu гъдулар, utworzony od tegoż za pomocą przyrostka -uн): Девет дни и девет нощи пиха вино и пяха песни четиримата. Един стар едноок гъдуларин им свиреше; гъдуларче (deminutivum od гъдулар, utworzone za pomocą bardzo produktywnego przyrostka -че, tworzącego deminutiva): Програмата е наредена от двамата учители, учителката и бай Божил кмета, който ще свири на кавал, като поканиха и кворавото Чоре - гъдуларчето; гъдуларски (przymiotnik od гъдулар, utworzony za pomocą formantu -ски): Гъдуларска песен; гъдулчица 'małe prymitywne ludowe skrzypeczki, może odpowiednik polskich mazanek'11 - budowa słowotwórcza jak цъгулчица

10 Zob. Граматика..., ор. cit., s. 67.

11 Mazanki to małe, ludowe skrzypeczki, o długości całkowitej ok. $50 \mathrm{~cm}$ (skrzypce mają długość całkowitą $60 \mathrm{~cm}$ ), o spodzie, bokach, szyjce i główce wydrążonych z jednego kawałka drewna i sklejonych z płytą wierzchnią, o trzech strunach, strojonych bardzo wysoko: $\mathrm{a}^{1}(440 \mathrm{~Hz})$, $\left.\mathrm{e}^{2}(659,3 \mathrm{~Hz}), \mathrm{h}^{2}(987,8 \mathrm{~Hz})\right)$, por. też B. Muchenberg, Pogadanki o muzyce, t. I, Warszawa 1978, 
(RBE, 3). Zaskakujący jest brak nomen agentis rodzaju żeńskiego - widocznie w bułgarskiej muzyce ludowej nie było skrzypków kobiet. Słownik Romanskiego definiuje znaczenie wyrazu гъдулка nieco inaczej, mianowicie: 'народен лъков музикален инструмент с 3 до 5 струни' - pol. 'ludowy instrument muzyczny smyczkowy o 3-5 strunach'. Oznacza to, że ten instrument wcale nie jest uproszczony, albowiem wszystkie współczesne instrumenty smyczkowe mają cztery struny, wyjątkiem jest kontrabas w odmianie tzw. orkiestrowej, który ma 5 strun (w odmianie solistycznej - cztery) ${ }^{12}$. Przykłady są następująсе: Циганите теглеха лька по гъдулките си и пееха с издути гърла; Сред голям крбг от войниии свиреха двама души - единият с кавал, другият с гъдулка (RSBKE, 1).

Български тълковен речник tłumaсzу wyraz гъдулка poprzez гусла (i vice versa) - ten ostatni jest dokładnym odpowiednikiem polskiego geśle.

Dokładniej opisuje ten instrument Christo Wakarelski w swojej monografii zatytułowanej Етнография на България. Pisze on, że ten instrument o korpusie w kształcie gruszki posiadał wypukłe dno, a od góry był pokryty cienką deseczką, w której wydrążone były dwa otwory rezonansowe (dowolnego kształtu, np. półokrągłe). Ta deseczka była połączona z dnem za pomocą kołeczka (słupka) - odpowiednika tzw. „duszy” w normalnych skrzypcach. Szyjka była stosunkowo krótka. Struny wykonane były najczęściej z jelit zwierzęcych lub z drutu. Zaczepione były na występie na dnie korpusu (drugi koniec nawinięty był na kołki). W okolicach otworów rezonansowych struny były podparte o próg zwany мazape. Podobnie jak w skrzypcach, gryf nie posiadał progów, stąd też tony wygrywało się na słuch. Autor zaznacza też, że w zależności od regionu Bułgarii instrumenty te mogą mieć różne rozmiary a także różną liczbę strun i różny strój. Гъдyлкa w Dobrudży jest mniejsza (długość całkowita 40-45 cm, szerokość korpusu 13-15 cm), a w innych rejonach Bułgarii ma długość całkowitą 50-55 cm i szerokość korpusu $18-22 \mathrm{~cm}$. Ta ostatnia jest także znana pod nazwą кемане. W Dobrudży гъдулка ma trzy struny o stroju: a $(220 \mathrm{~Hz}), \mathrm{e}^{1}(329,65 \mathrm{~Hz}), \mathrm{a}^{1}(440 \mathrm{~Hz})$, przy czym melodię się wygrywa zwykle na najwyższej, pozostałe są tzw. burdonowe. Inne tego typu instrumenty są czterostrunowe, przy czym strój jest zupełnie inny niż skrzypiec (nieco niższy), mianowicie: $\mathrm{f}(174,6 \mathrm{~Hz}), \mathrm{b}(233,1 \mathrm{~Hz}), \mathrm{f}^{1}(349,2 \mathrm{~Hz})$,

s. 25; Wielka encyklopedia powszechna, t. VII, Warszawa 1966, s. 142; J. Hab ela, Słowniczek muzyczny, Warszawa 2005, s. 109. Instrument ten używany był jeszcze na pocz. XX wieku w niektórych regionach Wielkopolski i Ziemi Lubuskiej.

${ }^{12}$ Historyczne instrumenty smyczkowe - viole miały więcej strun niż współczesne (viola de amore nawet $7+$ struny rezonansowe). 
$\mathrm{b}^{1}(466,2 \mathrm{~Hz})$. W wersjach z większą liczbą strun zwykle tylko dwie są melodyczne. Jednostrunowa гъдулка w Bułgarii nie jest współcześnie spotykana. Są świadectwa, że do końca XIX wieku takie instrumenty istniały w zachodniej Bułgarii (okręg radomirski i kjustendiłski) ${ }^{13}$.

Pod względem budowy słowotwórczej wyraz гъдулка przypomina literacką nazwę uигулка (utworzona jest za pomocą tego samego formantu). Nazwa ta pochodzi od onomatopeicznego rdzenia $2 ъ \partial-$, oznaczającego 'brzęczenie'. Z tegoż pierwiastka wywodzi się bułg. dial. czasownik гъдувам 'grać na ludowych skrzypcach (zwanych w języku bułgarskim гъдулкa)'. Czasownik ma odpowiedniki w innych językach słowiańskich, por. scs. ГжАнтн, ГжАх, гжАєшн; sch. gúdeti, gúdim 'grać na instrumencie strunowym'; słń. gósti, gódem; ros.

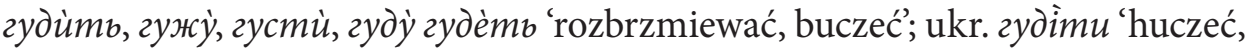
rozbrzmiewać, szumieć; czes. housti, hudu (por. hudba 'muzyka'); stpol. gasść, gędę (stąd: gęśle); głuż. hudźić. Wywodzi się z ps. pierwiastka ${ }^{\star} g o d-$, spokrewnionego z lit. gaũsti, gaudžiù 'dźwięczeć, brzęczeć'; łot. gàudas 'jęk'. Z tegoż rdzenia wywodzi się też rumuńskie gîndac 'chrząszcz ${ }^{\text {'14 }}$. Psł. ${ }^{*} g Q d-$ pochodzi $\mathrm{z}^{*} g u-n-d$, formy $\mathrm{z}$ infiksem nosowym (por. lit. gaũsti, gaudžiu), co należy do ie. `gou- 'wołać, krzyczeć', por. stind. gavate ‘brzmi'; gr. yó(F)o ‘narzekanie'; scs. говоръ 'wrzask, hałas'15.

Pod względem znaczenia zbliżony jest wyraz zycлa. Słownik języka bułgarskiego BAN definiuje go następująco: 'Народен лъков инструмент, разпространен у нас в миналото, който се изработва от цяло дърво, във формата на надлъжно прерязана круша, с дълга шийка и има само една струна' - pol. 'ludowy instrument smyczkowy, rozpowszechniony w dawnych czasach, wykonany z jednolitego kawałka drewna w kształcie przekrojonej gruszki, z długą szyjką i mający tylko jedną strunę’. Ilustruje go przykładami: Отскоро бе се завъртил в село, свиреше с гуслата, пееше, веселеше хората; Посвири, посвири на гуслата и попей, брате i inne (RBE, 3). Słownik ten wymienia też liczne derywaty. Jednym z nich jest zycrap 'mężczyzna grający na gęślach', nomen agentis, utworzone za pomocą produktywnego przyrostka - ар ${ }^{16}$. Przykłady: Пред замрежения си поглед сякаш виждаше как някой белобрад гуслар скъриа с гъдулката на хорището и реди дума след дума;

13 Zob. Х. Вакарелски, Етнография на България, София 1977, s. 400-402. Częstotliwości tonów na podstawie tabeli częstotliwości tonów.

14 Zob. Български етимологичен речник, t. I, София 1971, s. 299 (BER); B oryś SE, 159.

15 Zob. F. Sławski, Oboczność Q:u w językach słowiańskich, „Rocznik Slawistyczny” LV, 2005, s. 13.

16 Zob. Граматика..., ор. cit., t. II, s. 48-49. 
Деца пищяха със свирки, гуслари свиреха стари юнашки песни пред купове слушатели. Synonimem jest (dokumentowany przez tenże słownik) гусларин - przykład: Добре доили, девойки, привет от стар гусларин, с вас празника ни става по драг и льчезарен. Odnotowano też przymiotniki, utworzone od nomen agentis гуслар, mianowicie гусларев і гусларов (są synonimami). Utworzone są za pomocą formantu -oв (-eb) tworzącego przymiotniki dzierżawcze ${ }^{17}$. Przykłady: Никой гусларева орис не проумя; Гусларева майка. Słownik notuje też deminutivum гусларче 'млад гуслар' - pol. 'młody gęślarz', utworzone za pomocą najczęściej spotykanego w tej funkcji formantu -чe. Występuje także przymiotnik гусларски (derywowany za pomocą sufiksu - $c \kappa u)^{18}$ o znaczeniu 'dotyczący gęślarza, charakterystyczny dla gęślarza’. Przykład: Добри Христов намира например, че в много наши народни песни с кавалски и гусларски мотиви съществуват четвърттонови отношения. Udokumentowano też czasownik гусля 'grać na gęślach', przykład: Гуслар ми гусли по си медани... oraz nomen deverbale гуслене (RBE, 3).

Etymologicznie wyraz jest spokrewniony z гъдулка (wywodzi się z tego samego dźwiękonaśladowczego rdzenia). Гусла są wyrazem ogólnosłowiańskim, por. scs. гжскн; sch. güsle (güslē); słń. gộsli 'skrzypce’; pol. gęśle; cz. housle 'skrzypce'; słc. husle; głuż. huslě; dłuż. gusle; ros. гусли; ukr. гусли 'dawny instrument strunowy'; ps. ${ }^{\star}$ gosli $\left(<^{*} g Q d-s l i\right)$. Jest to więc nomen instrumenti, utworzone za pomocą przyrostka ${ }^{*}$ slb od psł. czasownika gosti, godo 'wydawać przeciągły głos, brzęczeć, buczeć, szumieć', wtórnie 'grać na instrumencie strunowym’ (Boryś SE, 159) ${ }^{19}$. Trzeba zwrócić uwagę na to, iż bułgarska postać гусла jest niezgodna $\mathrm{z}$ rozwojem ps. samogłoski $\varrho \mathrm{w}$ języku bułgarskim, gdzie $q>$ b, stąd prawidłowa byłaby postać гъcлa (zachowana w niektórych gwarach). Postać literacka гусла wywodzi się prawdopodobnie (tak pisze m.in. BER) z gwar zachodnich (wpływy języka serbsko-chorwackiego), gdzie instrument był wcześniej znany.

W języku starobułgarskim (staro-cerkiewno-słowiańskim) wyraz гжски, -нн oznaczał (wg danych Słownika starobułgarskiego BAN ${ }^{20}$ ): 'старинен музикален инструмент, подобен на арфа или цитра' - pol. 'stary instrument muzyczny, podobny do harfy lub cytry', czyli instrument strunowy należący

17 Zob. Граматика..., ор. cit., t. II, s. 153-154. Za pomocą tegoż przyrostka tworzy się m.in. nazwiska (często od imion).

18 Zob. Граматика..., op. cit., t. II, s. 154.

19 Por. W. Boryś, Kultura..., op. cit.

${ }^{20}$ Старобългарски речник, t. I, София 1999, s. 384. 
do grupy szarpanych (a nie smyczkowych). Znaczenie przetłumaczono poprzez gr. $\kappa \iota \vartheta \dot{\alpha} \rho \alpha, \psi \alpha \lambda \tau \dot{\eta} \rho ı$. Słownik ilustruje leksem licznymi przykładami. Oto niektóre z nich: въстані слово моҺ. въстані пьсалътЫръ и гж

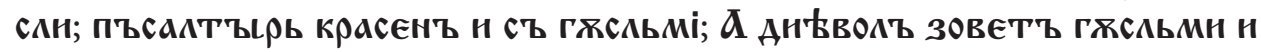
ПААсьци п中'Мн непрньзнннамн. Słownik staro-cerkiewno-słowiański ${ }^{21}$ wydany w Moskwie rejestruje rzeczownik гжскн, tłumacząc jego znaczenie

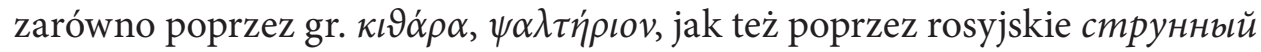
инструмент oraz poprzez czeskie strunný nástroj. Oznaczałoby to, iż wyraz ten ma szeroki zakres znaczeniowy, odnosi się bowiem do 'instrumentu strunowego' w ogóle, a takich instrumentów muzycznych jest wiele. Ilustruje go

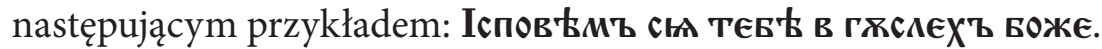

Bułgarski język literacki zna też inną nazwę skrzypiec - виолина. Słownik języka bułgarskiego BAN zamieszcza ją z kwalifikatorem rzadko i tłumaczy przez цигулка. Opatruje ją jednym przykładem: Най-образиовият му (на Рафаело) nортрет е момбкбт с виолина, който се пази в двореияа на княз Шарра в Рим. Słownik ten notuje również derywaty: виолинов 'skrzypcowy' - bułg. 'цигулков', przykłady: Един от най-трудните концерти във виолиновата литература, това е Брамсовът; Виолинова партитура; виолинен 'ts.' a także złożenia виолин-виртуоз 'muzyk - wirtuoz skrzypiec', przykład: Пред Военния клуб бе се натрупала такова навалииа, каквато не бе имало от дълго време. Може би прочутият виолин-виртуоз бе привлякбл толкова много хора; виолин-виртуозка 'kobieta muzyk - wirtuoz skrzypiec' (bez przykładów; RBE, 2). Odnotowano też wyrazy виолонист [książk.] 'skrzypek' oraz виолонистка 'skrzypaczka', przykład: В пет часа тая вечер младата, току-що излязла на сцена виолонистка даваше втория си концерт (RBE, 2). Postać fonetyczna wyrazu виолонист wskazuje na bezpośrednie zapożyczenie $\mathrm{z}$ francuskiego violoniste 'skrzypek, skrzypaczka'.

Виолина jest zapożyczeniem $\mathrm{z}$ włoskiego violino 'skrzypce'22, będącego derywatem (deminutivum) od viola 'instrument smyczkowy', np. viola de amore (współcześnie odpowiada jej altówka), viola de gamba (późniejszym odpowiednikiem jest wiolonczela) i inne z tej rodziny (pierwotne znaczenie 'bratek wonny, fiołek', bułg. 'теменуга', które rozwinęło się na instrumenty muzyczne, których korpus ma kształt liścia tej rośliny). W języku bułgarskim również funkcjonuje wyraz виола, lecz oznacza on inny, nieco większy od

${ }^{21}$ Старославянский словарь (по рукописям X-ХІ веков), под ред. Р. М. Цейтлин, Р. Вечерки, Э. Благовой, Москва 1999, s. 181.

${ }^{22}$ W języku polskim jest tylko klucz wiolinowy zwany inaczej (rzadziej) kluczem skrzypcowym. 
skrzypiec (współczesny) instrument smyczkowy, o niższej skali - altówkę (derywaty: виолист 'altowiolista', виолистка 'altowiolistka') ${ }^{23}$.

W Słowniku języka bułgarskiego BAN odnotowano też wyraz кеманѐ (z adnotacją, że występuje oboczna postać кеменè). Opatrzono go kwalifikatorem przestarzały i dialektalny. Odnotowano go w trzech znaczeniach, przy czym pierwsze zostało wytłumaczone poprzez literacki wyraz цъигулка. Został on zilustrowany dwoma przykładami: В залата за пушене свиреше оркестьр от тимпани, саксофони и кеманета. Гръмна ученически оркестьр. Не популярните тогава зурла, тьпан и кемане - а флау, пиколина. Drugie znaczenie omawianego wyrazu zostało zdefiniowane jako 'гъдулка, кеменче'. Chodzi o małe, ludowe skrzypeczki. Przykład: Свирех аз там с кемането си, това де, дето му викат още гъдулка. Trzecie znaczenie, $\mathrm{w}$ jakim odnotowano interesujący nas leksem, to 'głowa, dynia' - bułg. 'глава, кратуна, тиква, куфалница' (opatrzone zostało kwalifikatorem przenośnie, ironiczne; RBE, 7).

Tenże słownik zamieszcza też pewną liczbę derywatów, utworzonych od interesującej nas nazwy. Jednym z nich jest кеманеджия (кеманджия) - jako tytuł grzecznościowy także кеманджи о znaczeniu 'skrzypek', bułg. 'цигулар'. Wymienia też warianty tej nazwy: кеменджия і кеменчеджия. Znaczenie to nie zostało zilustrowane żadnym przykładem. Drugie znaczenie (według tego słownika) to odpowiednik bułgarskiego гъдулар. Niemniej jednak ицгулар і гъдулар są wyrazami niemalże synonimicznymi (różnica polega na tym, że гъдулар то 'muzyk grający na ludowych skrzypkach'). Jest ono zilustrowane dwoma przykładami: Момкови си условят гайдарджии или кеманеджии, които да свирят от събота до сряда заранта, докогато се свърии сватбеният обичай; Засвирил ми кеманджи Генчо със кемането насред хорото. Odnotowano pochodzący od tej nazwy rzeczownik каменджийка о znaczeniu 'żona skrzypka' - bułg. 'жена на кеменджия' z adnotacją, że znaczenie to zaczerpnięto ze słownika Gerowa, oraz 'skrzypaczka' - bułg. 'жена, която свири на кемане, цигуларка', a także deminutivum кеменджийче (przestarzałe, dialektalne) 'mały lub młody skrzypek' (za słownikiem Gerowa). Słownik zamieszcza też przymiotnik кеменджийски (przestarzałe, dialektalne) 'dotyczący skrzypka' (także z adnotacją, że zaczerpnięty ze słownika Gerowa). Przymiotnik ten utworzono za pomocą produktywnego przyrostka - $к \kappa u$. Udokumentowano także deminutivum кеменче. Słownik (RBE, 7) notuje je w dwu znaczeniach:

${ }^{23}$ Altówka ma długość całkowitą większą o ok. 6 cm niż skrzypce (z czego ok. $5 \mathrm{~cm}$ różnicy przypada na korpus, więc szyjka jest proporcjonalnie krótsza), posiada cztery struny, strojone o kwintę niżej niż skrzypce: c (130,8 Hz), g (196 Hz), d (293,7 Hz), a1 (440 Hz). 
1. 'skrzypce' - bułg. 'цигулка', przykład: Главни градове в Италия ... Кремола на река По, прочут с кеменчетата си и струните си, 2. 'ludowe, prymitywne skrzypce' - bułg. 'гъдулка'. Przykłady: Дядо Вичо извади от простия, скърпен от стари възглавки „кальф” гъдулката. Опря я до голямото си ляво ухо, замлькна. Плю на рбце, потри ги, замаза шийката на кеменчето и пак зацьнка по струните; Циганите от долната махала на Чучулигово бяха дошли с кеменчетата си, с кларнета и тъпана. Odnotowano też nomen agentis кеменчеджия (przestarzałe, dialektalne) będące synonimem кеманеджия. Przykład: Заре кеменчеджията понагря рғиете на печката, намази лька с чамсакъз и засвири 'селското хоро' (RBE, 7).

Nazwy te pochodzą z perskiego kemān 'tęcza' i zostały zapożyczone do języka bułgarskiego poprzez tureckie keman, kemâne. Występują też w innych językach bałkańskich, por. sch. ćemáne, ćeméne; arum. kimane; rum. cheman; alb. qemanxhé, qemenxhé. Nomen agentis кеменджия nie jest derywatem na gruncie bułgarskim, lecz zapożyczeniem z tur. nomen agentis kemençı, podobniе кеменчеджия (z tur. kemençесı). Także postać кеменче jest bezpośrednim zapożyczeniem z tur. kemençe (BER 2, 324-325).

Najden Gerow w swoim Słowniku odnotował też nazwę 'skrzypiec' гънийлка. Tłumaczy je poprzez synonimy: цицулка, гъдулка, кемене oraz przez ros. скрипка, nie ilustrując żadnym przykładem. Nie odnotowują tej nazwy inne słowniki, nawet wielki BAN-u ani też Słownik wyrazów rzadkich, gwarowych i przestarzałych ... ${ }^{24}$. Trudno też objaśnić jej pochodzenie. BER nie zamieszcza tego wyrazu w ogóle. Analizując budowę morfologiczną tego rzeczownika, można wyodrębnić złożony przyrostek - илкa $(-u \pi+-\kappa a)^{25}$ oraz pierwiastek $2 \preccurlyeq H_{-}$. Przyrostek ten należy do nomen instrumenti (najczęściej od podstaw werbalnych) i występuje w takich wyrazach, jak np. сабилка, теглилка, точилка itp. Problemem jest ustalenie znaczenia pierwiastka. Normalnie bułgarski czasownik гъна ma znaczenie 'giąć', a więc zupełnie oddalone od semantyki derywatu (jedynie smyczek może być wygięty). Niemniej jednak Słownik BAN-u notuje również czasownik ten w stronie zwrotnej гъна ce, podając oprócz podstawowych także rzadkie znaczenie (o głosie) 'brzmieć nierównomiernie, raz silniej, raz słabiej' - bułg. 'за глас - звуча с повишавания и понижавания, с извивки', a więc jest to znaczenie związane z 'wydobywaniem głosu, dźwięku'. Znaczenie to zostało opatrzone przykładem z Diczewa: При това

${ }^{24}$ Речник на редки, остарели и диалектни думи в литературата ни от XIX и XX век, под ред. на Ст. Илчев, София 1974.

${ }_{25}$ Zob. Граматика..., ор. cit., t. 2, s. 59. 
гласът му се гънеше и извиваше, сякаш Касабов не беше в стаята, и на някаква сиена и какво с тоя глас, така и сжестовете си той изразяваше задоволство от прочетеното. Niemniej jednak nie można stwierdzić, by interesujący nas wyraz bez wątpliwości pochodził od tego czasownika.

Inna nazwa 'skrzypiec' odnotowana w słowniku Gerowa to rayma. Autor tłumaczy ją przez synonimy: цигулка, гњдулка, гънилка, виулецъ, кемене oraz przez ros. скрипка. Słownik ten wymienia również derywat лаутар o znaczeniu 'skrzypek' (tłumaczy go następująco: 'който свири съ лаутп, свирачь, цигуларь, гждуларь, кеменеджиг' oraz przez rosyjski wyraz скрипачь). Derywat ten jest regularnie utworzonym nomen agentis za pomocą produktywnego przyrostka -ap. Rzeczownik rayma został również odnotowany przez Słownik BAN-u w dwóch znaczeniach: 1. (przestarzałe) 'струнен музикален инструмент, подобен на китара' - pol. 'strunowy instrument muzyczny, podobny do gitary (prawdopodobnie lutnia)'. Słownik ilustruje go dwoma przykładami. Oto jeden z nich: Както навсякъде по румънската земя, и тук свиреха иигани: две ицгулки, един изимбал, лаута. Drugie znaczenie, w jakim słownik odnotował interesujący nas rzeczownik, to 'skrzypce' - bułg. 'цигулка', przy czym jest ono opatrzone kwalifikatorem dialektalne. Nie zostało ono opatrzone żadnym przykładem. Słownik ten cytuje je za Georgiewem i za BER. Odnotowano tu także nomen agentis raymap (przestarzałe i dialektalne) 'muzyk grający na lutni' - bułg. 'свирач на лаута'. Nazwę tę opatrzono przykładami: $И$ аз обичам ... аз, като вляза нейде на панаира и кажа на таутарите: Свирете! ... (RBE, 8). Rzeczownik rayma w znaczeniu 'strunowy instrument muzyczny podobny do gitary’ został również odnotowany przez Słownik wyrazów rzadkich, przestarzałych i gwarowych ... (w słowniku tym zamieszczono również nomen agentis raymap). Słownik etymologiczny języka bułgarskiego znaczenie 'instrument muzyczny podobny do gitary' lokalizuje w miejscowości Samokow, natomiast znaczenie 'skrzypce' jako charakterystyczne dla dialektu miejscowości Nowo Seło (Widyńsko). Wymienia też nazwę miejscową Лаута (w okolicach Płowdiwu) i derywaty. Wyraz rayma (wg BER) zapożyczono za pośrednictwem rum. lăută 'lutnia, skrzypce ${ }^{26}$, gdzie jest pożyczką z niem. Laut, co pochodzi z wł. leúto, liuto a to z kolei z tur. laut(a), arab. alud 'drewno’, później 'instrument drewniany’. Wyraz ten jest znany również w języku

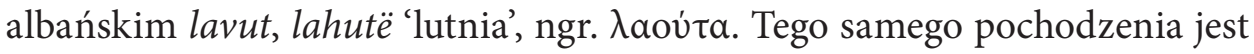
rzeczownik лютня (BER 3, 325, 584).

${ }^{26}$ W języku rumuńskim normalnie używaną nazwą 'skrzypiec' jest vioară (pochodzenia romańskiego). Jest to dokładny odpowiednik włoskiego viola. 
Słownik Gerowa w tomie uzupełniającym zamieszcza również rzeczownik oznaczający 'skrzypce' - виулица. Słownik wyjaśnia jego znaczenie poprzez bułg. гънилка, гъдулка, кемане, лаута, лира, цигулка. Wynika z tego, że ma nieco szerszy zakres znaczeniowy, odnosi się bowiem także do innych instrumentów strunowych, np. liry. Gerow zaznacza, że występuje w dialekcie gornodżumajskim. Pod względem słowotwórczym виулица jest deminutivum od виула, utworzonym za pomocą przyrostka -uน,a, będącego jednym z najczęściej występujących formantów tworzących rzeczowniki zdrobniałe ${ }^{27}$. W języku literackim rzeczownik ten musiałby mieć postać виолица (deminutivum od виола 'altówka'). Taką postać odnotowuje jedynie Słownik etymologiczny języka bułgarskiego, zaznaczając, że występuje tylko w gwarze Błagoewgradu (BER 1, 150).

Przyjrzyjmy się teraz występowaniu nazw 'skrzypiec' w innych językach słowiańskich.

W języku macedońskim nie odnotowano wyrazu będącego odpowiednikiem bułgarskiej nazwy цицулка. Występuje natomiast wyraz гадулка (odpowiednik bułg. гъдулка) a także deminutivum гадулица 'ts.'. Znaczenie macedońskiego гадулка to 'rodzaj ludowego instrumentu smyczkowego' - sch. 'vrsta narodnog gudačkog instrumenta ${ }^{\text {'28 }}$. Odnotowano także nomen agentis zaдyлар będące dokładnym odpowiednikiem, także pod względem znaczenia, bułgarskiego гъдулар. Język macedoński zna również rzeczownik гycлa (odpowiednik bułgarskiego гусла) oraz derywaty: nomen agentis гуслар i nomen actionis гуслене a także przymiotnik гусларски. Język macedoński zna także (obcy bułgarszczyźnie) nomen agentis гудач 'skrzypek' (utworzony od rdzenia гyd- za pomocą przyrostka -au), a także przymiotnik гудачкu 'smyczkowy' (RMJ, 1).

Podczas gdy w języku bułgarskim wyraz виолина używany jest bardzo rzadko i uchodzi za książkowy, w języku macedońskim jest on podstawową nazwą 'skrzypiec'. Występuje też frazeologizm: свири втора виолина 'grać drugie skrzypce’ (Słownik języka macedońskiego nie podaje odpowiednika pol. grać pierwsze skrzypce). Odnotowano także derywaty: виолинист 'skrzypek', виолинистка 'skrzypaczka', виолински 'skrzypcowy'. Tu należy zwrócić uwagę na to, że wyraz виолинист nie jest derywatem na gruncie macedońskim, lecz zapożyczeniem (natomiast виолинистка jest regularnie utworzonym rzeczownikiem rodzaju żeńskiego za pomocą przyrostka - $a$; RMJ 1).

27 Zob. Граматика, т. II, София 1983, с. 67.

28 Речник на македонскиот јазик, t. I-III, Скопје 1961-1966 (RMJ). Słownik ten tłumaczy znaczenia wyrazów poprzez język serbsko-chorwacki. 
Odpowiednikiem bułgarskiego кемане jest w języku macedońskim ќемане mające znaczenie 'skrzypce - synonim wyrazu виолина'. Wyraz ten posiada również drugie znaczenie 'głowa człowieka, dynia, okrągła manierka z drewna' - sch. 'glava čoveka, tikva, čutura'. RMJ opatruje ten wyraz kwalifikatorem archaiczny. Odnotowano też nomen agentis (także z kwalifikatorem archaiczny) ќеманеиија 'skrzypek'. Ten ostatni jest w całości zapożyczeniem z języka tureckiego, przez co na gruncie macedońskim nie można go uznać za derywat. Pozostałe bułgarskie nazwy 'skrzypiec' nie mają odpowiedników macedońskich.

W języku serbsko-chorwackim podstawową nazwą 'skrzypiec' jest violína. Nazwa ta jest pochodzenia włoskiego (etymologię omówiono w części artykułu poświęconej nazwom 'skrzypiec' w języku bułgarskim). Tzw. Słownik Macierzy serbskiej (RMS 1$)^{29}$ definiuje znaczenie tego wyrazu następująco: 'gudački instrumenat sa četiri strune' - pol. 'instrument smyczkowy czterostrunowy'. Definicja ta nie jest precyzyjna, albowiem wszystkie (poza instrumentami ludowymi a także kontrabasem w odmianie orkiestrowej) współczesne instrumenty smyczkowe mają cztery struny. Słownik zamieszcza frazeologizm (wyrażenie) prva violina podając dwa znaczenia: a) 'violina, koja vodi u orkestru' - pol. 'skrzypce, odgrywające wiodącą rolę w orkiestrze'; b) 'onaj, koji ima glavnu reč u čemu' - pol. 'ktoś, kto odgrywa gdzieś główną rolę’. Nota bene, frazeologizm ten ma dokładny odpowiednik w języku polskim. Słownik ten zamieszcza liczne derywaty, jak violinist 'skrzypek' - sch. 'svirač, umetnik na violini', violinistkinja 'skrzypaczka' - sch. 'ženska osoba violinist', violinistica 'ts.', viòlīnsk $\bar{l},-\bar{a},-\bar{o}$ 'dotyczący skrzypiec, wiolinowy', np. violinska futrola, viòlinskī ključ ' klucz wiolinowy'. RMS rejestruje także deminutivum violínica i opatruje je przykładem: Drhće svilena žica plahe violinice. W słowniku tym odnotowano również przymiotnik violínin, $-\bar{a}, \bar{o}$ 'koji pripada violini' - pol. 'należący do skrzypiec, skrzypcowy'. Zilustrowano go przykładem: Nogama i nehotično odgovaraju taktu violininih žica.

Język serbsko-chorwacki zna także ogólnosłowiańską nazwę güsle, güsālā, zdefiniowaną przez RMS następująco: 1. 'narodni muzički gudački instrument s nekoliko konjskih struna složenih kao jedna žica, uz koji se pevaju junačke narodne pesme' - pol. 'ludowy instrument smyczkowy o kilku strunach z końskiego włosia skręconych w jedną, przy którym się śpiewa ludowe pieśni bojowe, gęśle', przykł: Stoljetni plač javora, jauk gusala; 2. 'violina' - pol. 'skrzypce’. Przykłady: Za staklenim čedom umornih kafana cvile gusle kraj klavira; Šumori cimbal, cigili gusle; 3. 'čudo, nešto za priču' - pol. 'cud, coś, co się opowiada'. Przykład: Sad ćeš čuti tvojih gusala po selu!. Wariantem fonetycznym tej na-

29 Речник српскохрватског книжевног језика, t. I-VI, Novi Sad 1967-1976 (RMS). 
zwy jest güsli, gùslī ‘ts.’. Przykład: Natežite žice na guslima (RMS 1). Słownik $\mathrm{JAZU}^{30}$ zamieszcza niniejszy wyraz, zaznaczając, że w naszych czasach pisarze go używają także dla nazwania każdego instrumentu smyczkowego (skrzypiec, altówki, wiolonczeli, kontrabasu). Od nazwy güsle // güsli odnotowano wiele derywatów. Jednym z nich jest złożenie guslòżica 'struna skrzypiec' - sch. 'žica na guslama' (słownik zaznacza, iż wyraz ten został zaczerpnięty z jednej pieśni). Przykład: Obilujem svakim miljem; milim zvukom gusložica (RJAZU).

Odnotowano także inne derywaty, takie jak güslice (dem. od gusle), przykł.: Sadeljajte guslice od suvoga javora; Klavirić, guslice i cimbalići ... da proplačem od zanosa; gùslati, -ām 1. 'gudeti uz gusla; svirati na bilo kom gudačkom instrumentu' - pol. 'grać na gęślach lub jakimkolwiek instrumencie smyczkowym’, przykład: Bila je nedelja, u gostioni guslaju vatreni cigani; 2. (przenośnie) 'zanovetati, stalno ponavljati, govoriti jedno te isto' - pol. 'stale powtarzać, mówić jedno i to samo': Puna tri dana gusla jednu remi poeziju sa Dancem Andersonom; güsliti, -ìm 'ts.', przykł.: Guslile su gusle javorove; güslar 'čovek, koji gudeći uz gusle peva pesmu, obično junačku' - pol. 'człowiek, który grając na gęślach, śpiewa pieśni, zwykle junackie', przykł: Posle službe potražimo guslare, Došao je guslar; gùslač, -áča 1. 'ts.', przykł: Guslač gusli u Muhamedaginoj sobi; 2. 'skrzypek' - sch. 'violinist'. Przykład: Koncerat na kojem će neki strani umetnik, glasoviti guslač, izvodi nekoje komade; guslàčica 'skrzypaczka' - sch. 'žena guslar, violinistkinja', przykład: Beata, također izvrsna guslačica, izdrhtala je sa svakim titrajem struna; gùslačk $\bar{\imath},-\bar{a}, \bar{o}$ 'koji se odnosi na guslače, na muzičare koji sviraju na gudačkim instrumentima' - pol. 'odnoszący się do skrzypków oraz muzyków grających na pozostałych instrumentach smyczkowych', przykład: Bio je to fini glazbeni zvuk, koji ne najednom prešao u lak, guslački unison. Odnotowano także derywaty fundowane przez rzeczownik güslar (a więc derywaty drugiego stopnia od rzeczownika güsle takie, jak: güslārev 'koji pripada guslaru' - pol. 'należący do gę́llarza, skrzypka'; güslärov 'ts.'; gùslārskī, $-\bar{a},-\bar{o}$ 'dotyczący gęślarza, skrzypka' - sch. 'koji se odnosi na guslare', przykład: U takvoj sredini, iz široke guslarske epike ... rađa se ... naša umjetna književnost; güslārski (adv.) 'na guslarski način, kao guslar' - pol. 'jak gęślarz, na sposób gęślarski’. Występuje także nomen deverbale guslanje.

Słownik JAZU notuje także inne derywaty, takie jak guslilac 'skrzypek (także muzyk grający na innym instrumencie smyczkowym)' - sch. 'gudač' (zaznaczając, że wyraz występuje tylko u jednego pisarza XVIII w.); guslitelj 'ts.'; gusliteljan 'należący do skrzypka' - sch. 'koji pripada gusliteljima'.

${ }^{30}$ Rječnik hrvatskoga ili srpskoga jezika, t. I-XXIII, Zagreb 1860-1986 (RJAZU). 
Język serbsko-chorwacki także zna (derywowany od innego tematu) czasownik gúdeti, gúdìm (oboczna postać gúditi, -ìm) 'grać na skrzypcach (lub innym instrumencie smyczkowym), brzdąkać, rzępolić', oraz derywaty od niego utworzone: gùdāč (gùdāc) ${ }^{31}$ 'muzyk grający na instrumencie smyczkowym', gùdāčkī 'smyczkowy', gùdalo (gùdilo) 'smyczek'.

Inną nazwą 'skrzypiec' jest bałkanizm, pochodzenia tureckiego (por. wyżej) ćemane, -ta, którą RMS tłumaczy przez nazwę 'violina' - pol. 'skrzypce' i ilustruje jednym przykładem: Pored ciganskog ćemaneta čule su se šumadijske gajde (RMS 6).

W języku serbsko-chorwackim nie odnotowano odpowiednika bułgarskiej nazwy цицглка, natomiast słowniki (RMS 6) podają czasownik (onomatopeiczny) ciguljati 'rđavo svirati na violini, škripati' - pol. 'nieczysto grać na skrzypcach, skrzypieć' oraz nomen deverbale ciguljanje.

Język słoweński zna takie nazwy 'skrzypiec' jak violina i gúsle. Violina - jak już wspomniano - jest wyrazem pochodzenia włoskiego. SSKJ ${ }^{32}$ tłumaczy znaczenie tej nazwy następująco: 'godalni instrument s štirimi strunami in visokim tonskim obsegom' - pol. 'instrument smyczkowy czterostrunowy o wysokiej skali'. Ilustruje to następującymi przykładami: igrati na violino, uglasiti violino, skladba za violino, učiti violino. Wymienia też frazeologizmy: biti druga violina 'biti v podrednom položaju' - pol. 'odgrywać drugorzędną rolę' oraz igrati prvo violino 'biti pri kakem dejanju ravnajnju vodilen' - pol. 'być w jakiejś sytuacji równym wodzowi'. Użyto też przykładu: biti prva violina Slovenije 'najboljši violinist' - pol. 'największy skrzypek (Słowenii)'. Słownik ten podaje także derywaty: violinist 'kdor igra violino' - pol. 'ten, kto gra na skrzypcach, skrzypek', przykład: igranje, nastop violinista; violinistka 'skrzypaczka'; violinski 'skrzypcowy', przykłady: violinska skladba, violinski koncert, violinski ključ G.

SSKJ odnotował także nazwę gúsle, -sel, tłumacząc ją następująco: 'ljudsko glasbilo z eno struno in močno upognenim lakom' - pol. 'ludowy instrument jednostrunowy z mocno wygiętym smyczkiem'. Opatruje go dwoma przykładami: igrati na gusle, pevec s guslami. Słownik ten wymienia też następujące derywaty: guslar 'ljudski pevec, ki spremlja svoje pesmi z igranjem na gusle' - pol. 'ludowy śpiewak (pieśniarz), który wykonuje swoje pieśni wraz z grą na gęślach’, przykład: poslušati pesmi guslarjev oraz fundowane przez ten ostatni rzeczownik adjectivum guslarski, - $a$, -o 'gęślarski', przykład: guslarske pesmi.

31 Rzeczownik gúdac ma inną fleksję niż gùdač: Gen. sg. gúca (Nom. gúdac) // Gen. sg. gudáča (Nom. gùdač).

32 Slovar slovenskega knjižnega jezika, t. I-V, Ljubljana 1970-1991 (SSKJ). 
Przegląd nazw ‘skrzypiec’ w językach zachodniosłowiańskich zaczniemy od polszczyzny. W języku polskim podstawową nazwą są skrzypce. Słownik języka polskiego pod red. Mieczysława Szymczaka tłumaczy znaczenie tego wyrazu w sposób następujący: 'instrument muzyczny smyczkowy o czterech strunach strojonych w kwintach i skali powyżej czterech oktaw'. Ilustruje go następującymi przykładami: skrzypce Stradivariusa; tony, dźwięki skrzypiec; utwór na skrzypce, na czworo skrzypiec; stroić skrzypce, grać na skrzypcach; pierwsze, drugie skrzypce 'dwie różne partie skrzypiec, dwie grupy muzyków grających na skrzypcach w orkiestrze symfonicznej'. Wymienia też frazeologizm: grać pierwsze skrzypce 'mieć gdzieś decydujący głos, przewodzić, dominować, rządzić. Słownik ten wymienia następujące derywaty: skrzypcowy 1 . 'dotyczący skrzypiec oraz ich konstrukcji', przykłady: technika gry skrzypcowej; klucz skrzypcowy 'klucz wiolinowy'; 2. 'przeznaczony do gry na skrzypcach, wykonywany na skrzypcach'; etiudy skrzypcowe; solo skrzypcowe; koncert skrzypcowy. SJP wymienia też nomen agentis skrzypek 'muzyk grający na skrzypcach', przykłady: sławny skrzypek; pierwszy skrzypek 'główny skrzypek w orkiestrze symfonicznej, wykonujący partie solowe, koncertmistrz'; nomen agentis rodzaju żeńskiego skrzypaczka 'kobieta mająca wykształcenie muzyczne, grająca na skrzypcach'. Słownik ten wymienia też deminutivum skrzypki, zilustrowane przykładem lipowe skrzypki. Zdrobnienie to nie zawsze oznacza zmniejszenie fizycznych wymiarów instrumentu, lecz - przede wszystkim - wskazuje na niższą jego jakość (odnosi się zwykle do prymitywnego, ludowego instrumentu) - małe skrzypce dla dzieci oznacza się liczbą ułamkową, np. skrzypce 1/2, 3/4. Rzeczownik skrzypce pochodzi od czasownika dźwiękonaśladowczego skrzypieć 'wydawać charakterystyczny głos, skrzypienie' < psł. *skripěti // škripati 'wydawać charakterystyczny odgłos wywołany np. tarciem, skrzypieć, trzeszczeć, zgrzytać' (Boryś SE 555). Utworzony został za pomocą przyrostka -ica, por. stpol. skrzypica, występujące jako plurale tantum skrzypice, stąd późniejsze skrzypce. Nota bene, skrzypce wydają taki dźwięk jedynie podczas gry równoczesnych współbrzmień, na dwu strunach jednocześnie - dźwięk pojedynczy jest czysty, śpiewny. Nomen agentis skrzypek jest derywowane wprost od czasownika dźwiękonaśladowczego.

Inną nazwą są gęśle. Wyraz ten nie jest dokładnym synonimem skrzypiec, lecz oznacza (za SJP) 'dawny, prymitywny instrument muzyczny z szyjką lub bez szyjki o różnym kształcie pudła'. Słownik zamieszcza także deminutivum gęśliki 'małe, podłużnego kształtu gęśle', ilustrując hasło przykładem Grać na gęślach. Definicja użyta w SJP jest niedokładna - nie wynika z niej nawet to, że chodzi o instrument smyczkowy a nawet o strunowy. Dokładniej definiuje gęśle słowniczek muzyczny Jerzego Habeli: gęśle ‘stary, prymitywny, ludowy 
instrument smyczkowy, którego kształt i strój zmieniał się zależnie od epoki i terenu; dźwięki wydobywano przez pociąganie prymitywnym smyczkiem, rzadziej przez szarpanie; do dziś bywają używane m.in. na góralszczyźnie ${ }^{33}$. Pochodzenie wyrazu jest takie, jak bułg. zусла (por. wyżej).

Inną nazwą są mazanki. Wyrazu tego nie odnotował SJP pod red. Mieczysława Szymczaka. Wymieniany jest on jedynie w publikacjach poświęconych wiadomościom o muzyce, historii muzyki. Bohdan Muchenberg wymienia mazanki w znaczeniu 'małe skrzypeczki, które posiadały trzy struny i były strojone bardzo wysoko $\left(\mathrm{a}^{1}, \mathrm{e}^{2}, \mathrm{~h}^{2}\right)$, obecnie rzadko używane'. Zaznaczono, iż nazwa pochodzi od mazania smyczkiem po strunach (objaśnienie to jest przekonujące). O instrumencie tym wspomina także słowniczek muzyczny J. Habeli a także Wielka encyklopedia powszechna (por. przypis 9).

W języku czeskim podstawową nazwą 'skrzypiec' są housle (o tej samej proweniencji co bułg. zyсли; por. wyżej), zdefiniowane przez PSJČ ${ }^{34}$ następująco 'hudební smyčcový nástroj o čtyřech strunách, z nich nejnižší je g a ostatní jsou vždy o kvintu vyžší' - pol. 'instrument muzyczny smyczkowy o czterech strunach, z których najniższa to g, a kolejne są wyższe o kwintę (od poprzedzającej)'. Przykłady: Muzikanti ladili housle; Hral na housle. Słownik wymienia też liczne derywaty od tego rzeczownika, np. houslista, -y 'hrač na housle' - pol. 'muzyk grający na skrzypcach', przykład: Housliste třepotali smyčcem; houslař, -e 1. 'vyrobce housli a jiných smyčcovych nástrojů' - pol. 'rzemieślnik artysta wytwarzający skrzypce i inne instrumenty smyczkowe, lutnik', 2. (archaiczne) 'houslista' - pol. 'skrzypek'; houslařiti 'povodovati houslařskom živnost; dílati houslařskou práci' - pol. 'wykonywać pracę lutniczą'; houslařství 'vyroba houslí a jiných smyčcových nástrojů; obchod z nimi' - pol. 'wyrób skrzypiec i innych instrumentów smyczkowych, lutnictwo; sklep muzyczny wyspecjalizowany w sprzedaży instrumentów smyczkowych'; houslařský 'lutniczy', przykład: Přes dvěstě let je uměně houslar̆ské nezměnné; housliř (archaiczne) 'lutnik' - pol. 'odpowiednik czes. houslař', przykład: Gabriel Waldstorch byl syn housliře; housličky, -ček (deminutivum, często ekspresywne od housle 'skrzypeczki'), przykład: Učitel chodíl mezi námi s housličkami v ruce; housličkovátý 'mající podobu housliček' - pol. 'mający kształt skrzypeczek'; przykład: Děti plochych housličkovitých prsíček (PSJČ).

W języku czeskim istnieje też międzynarodowa (pochodzenia włoskiego) nazwa 'skrzypiec' violino. PSJČ wymienia ją, nie podając żadnego przykładu. Obok niej wymienia nazwę violina 'housle, violino' - pol. 'skrzypce', zaznacza-

${ }^{33}$ J. Habela, Stowniczek..., op. cit. s. 70.

34 Př́ruční slovník jazyka českého, t. I-VIII, Praha 1935-1957 (PSJČ). 
jąc, iż jest to wyraz literacki. Zamieszcza też następujące derywaty: violinista 'houslista' - pol. 'skrzypek', violinistka 'houslistka' - pol. 'skrzypaczka'.

W języku słowackim (podobnie jak w czeskim) podstawową nazwą 'skrzypiec’ są husle (G. husiel'). KSSJ ${ }^{35}$ definiuje znaczenie wyrazu następująco: 1. 'sláčikový hud. nástroj so štyrmi strunami ladenými v kvintach' - pol. 'instrument muzyczny smyczkowy o czterech strunach strojonych w kwintach', przykłady: koncertne husle, hrat' na huslach. Słownik zamieszcza też frazeologizm hrat prvé, druhé husle 'mat' vedúcu, podradnú úlohu' - pol. 'pełnić wiodącą / podrzędną funkcję. Drugie znaczenie wyrazu husle to (potocznie) 'huslova hra' - pol. 'gra na skrzypcach'. Przykład: chodit' na husle. Słownik ten odnotował też następujące derywaty: huslista 'kto hrá na husliach' - pol. 'skrzypek'; huslistka 'skrzypaczka'; husliar 'výrobca husiel' a iných sláčikových nástrojov' - pol. 'rzemieślnik artysta wytwarzający skrzypce i inne instrumenty smyczkowe, lutnik'. Słownik słowacko-polski ${ }^{36}$ wymienia też takie wyrazy jak huslový 'skrzypcowy', przykłady: huslový koncert, huslové struny, huslová skladba; huslový kluč 'klucz wiolinowy, klucz skrzypcowy'; huslarsky 'lutniczy'. KSSJ ani SSP UJ nie notują innych nazw 'skrzypiec'.

W języku górnołużyckim podstawową nazwą 'skrzypiec' są również husle. Słownik Pfuhla ${ }^{37}$ tłumaczy ten rzeczownik (jako wyraz hasłowy podaje 1. poj. husla) poprzez niem. 'Geige, Wioline'. Wymienia następujące derywaty: huslowy 'geigen'; husliski 'ts.; huslacy 'ts.'; husleŕ, -rja 'Geiger, Fiedler' - pol. 'skrzypek'; huslerić 'Geiger sein, als Geiger leben' - pol. 'być skrzypkiem'; Husleŕstwo 'Geigenspielschaft' - pol. 'gra na skrzypcach'; huslować 'geigen, fiedeln' - pol. 'gra na skrzypcach'; huslowaŕ 'Geiger' - pol. 'skrzypek'; huslowanje ‘Geigen' - pol. 'gra na skrzypcach'. Słownik górnołużycko-polski Henryka Zemana ${ }^{38}$ podaje wyraz husle 'skrzypce', przykład: hra na husle, oraz derywaty: huslak 'skrzypek, grajek'; husler 'skrzypek'; huslerka 'skrzypaczka'; huslički 'małe skrzypce, skrzypeczki'; husliski 'skrzypcowy'; huslojty 'podobny do skrzypiec'; huslowar 'skrzypek'; huslować 'grać na skrzypcach'; huslowy 'skrzypcowy', np. huslowa křinka 'futerał na skrzypce'.

W języku dolnołużyckim 'skrzypce' to gusle. Słownik Arnošta Muki ${ }^{39}$ rejestruje rzeczownik gusle, -ow, podając znaczenia 1. 'die Geige, Fiedel, Violine;

${ }^{35}$ Krátky slovník slovenského jazyka, Bratislava 1989 (KSSJ).

36 Z. Jurczak-Trojan, H. Mieczkowska, E. Orwińska-Ruziczka, M. Papierz, Słownik słowacko-polski, t. I-II, Kraków 1998 (SSP UJ).

37 Ch. Th. Pfuhl, Lausitzisch Wendisches Wörterbuch, Bautzen 1886.

${ }^{38}$ H. Zeman, Słownik górnołużycko-polski, Warszawa 1967.

39 E. Muka, Słownik dolnoserbskeje rečy a jeje narečow, t. I-III, Petrohrad - Praha 1911-1928. 
скрипка' - pol. 'skrzypce’; 2. 'die Harfe' - pol. 'harfa'. Słownik ten zamieszcza też derywaty, takie jak: guslaŕ 'der Geigenspieler, Geiger, Fiedler; скрипач' - pol. 'skrzypek'; guslene 'das Geigenspielen, Geigen, das Violinspiel; игра на скрипке' - pol. 'gra na skrzypcach'; guslowańe 'ts.'; gusliś, -im (guslowaś, -aju) 1. 'geigen, fiedeln, Geige, Violine spielen; играть на скрипке' - pol. 'grać na skrzypcach', 2. 'Harfe spielen' - pol. 'grać na harfie'. Inne wyrazy należące do tego gniazda słowotwórczego posiadają znaczenia związane z 'zabobonami, gusłami, czarami', np. guslowaŕ 'guślarz, czarodziej, der Hexenmeister', guslowaŕka 'czarodziejka, guślarka', guslowaŕstwo 'Hexerei, guślarstwo', guslowaŕski 'guślarski, czarodziejski'. Także wyraz guslaŕ oprócz znaczenia 'skrzypek' występuje w sensie 'czarodziej, guślarz, niem. der Zauberer, Beschwörter', a czasownik guslowaś oprócz 'grać na skrzypcach' oznacza 'czarować, podobnie nomen deverbale guslowańe 'das Zaubern, Hexen, czarodziejstwo'. Te pary znaczeniowe traktowane są przez słownik jako homonimy (oddzielne hasła), niemniej jednak nie jest to uzasadnione, albowiem mamy tu do czynienia nie $\mathrm{z}$ homonimią, lecz polisemią. Wyrazy te mają bowiem wspólne pochodzenie (od psł. ${ }^{\star} g Q s t i$, godo, względnie od wariantu ${ }^{\star}$ gusti, gudo, ze starą obocznością $Q: u$ ). Pierwotne znaczenie 'granie na instrumencie strunowym, na gęślach' > 'wprawianie muzyką w stan ekstazy' > 'obrzędy magiczne (odprawiane $\mathrm{z}$ towarzyszeniem muzyki)' (por. Boryś SE 188).

W języku Drzewian Połabskich nazwą 'skrzypiec' było gigléikia lub giglia, przy czym ten pierwszy wyraz jest deminutivum utworzonym od drugiego za pomocą przyrostka -aika < *ika. Giglia pochodzi z niem. Geige i jest zapożyczeniem wprost $\mathrm{z}$ dolnoniemieckiego gìg'l 'Geige ${ }^{\text {' }}$.

Przegląd nazw 'skrzypiec' w językach wschodniosłowiańskich rozpoczniemy od rosyjskiego. W języku tym podstawową nazwą 'skrzypiec' jest скрѝnка, nomen instrumenti utworzone od dźwiękonaśladowczego czasownika скрипѐmь (< psł. ${ }^{*}$ skripéti). SSRLj ${ }^{41}$ definiuje wyraz cкрùnкa, -u następująco: 'струнный смычковый музыкальный инструмент' - pol. 'strunowy smyczkowy instrument muzyczny'. Definicja ta nie jest ścisła. Przykłady: На время притихнув, положили возле себя цимбали, скрипки и бубнь; Двое музыкантов - скрипка и арфа - играли вальс. Słownik ten wymienia frazeologizm первая скрипка 1. 'скрипач, исполняющий в струнном или симфоническом оркестре первый голос, самый выразительный и важный' - pol. 'skrzy-

40 Zob. R. Olesch, Thesaurus lingue draveanopolabicae, t. I: A-O, Köln - Wien 1983, s. 309.

${ }^{41}$ Словарь современного русского литературного языка, t. I-XVII, Москва - Ленинград 1948-1965 (SSRLJ). 
pek realizujący w orkiestrze symfonicznej, strunowej (smyczkowej) pierwszy głos, najważniejszy i najbardziej wyrazisty, pierwsze skrzypce’, 2. (przenośnie) 'о человеке, которому принадлежит в чем-либо важная, ведущая роля' - pol. 'o człowieku odgrywającym gdzieś ważną, wiodącą rolę.

SSRLJa podaje także inne wyrazy należące do tego gniazda słowotwórczego, takie jak: скрипочка (deminutivum), przykład: $Я$ подгрывал на самодельной скрипочке; скрипйца 1. (archaiczne, dialektalne) 'skrzypce' (por. staropol. skrzypica, skrzypice), przykł.: По воскресеням у шинка две скрипицы и контрабас наяривали плясовые мотивы; 2. 'rodzaj grzyba'; скрипичный 'dotyсzа̨су skrzypiec', przykł.: скрипичные струны, скрипичный квартет Шумана; zestawienie скрипичныци ключ 'klucz wiolinowy, klucz skrzypсowy'; скрипач 'skrzypek', przykłady: слепой скрипач в трактире; скрипачка 'skrzypaczka', przykład: На гастроли в кониертах приехала восходящая звезда, прекрасная скрипачка.

W języku rosyjskim znany jest także wyraz zycлu, przy czym jego znaczenie jest nieco inne. Słownik Ożegowa ${ }^{42}$ definiuje znaczenie tego wyrazu następująco: 'старинный струнный щипковый музыкальный инструмент' - pol. 'dawny szarpany instrument muzyczny'. Z definicji tej wynika, że może to być lutnia (jest bardzo dawnym instrumentem). Słownik ten odnotował też derywat гусляр 'музыкант, народный певец, играющий на гуслях' - pol. 'muzyk bądź śpiewak ludowy grający na gęślach'. Słownik Dala ${ }^{43}$ także notuje go w postaci гусли w znaczeniu 'род лежачей арфы, фортепиано, в четире октави, без клавишей, играющий перебирает проволочныя струны пальцами'. Definicja ta wskazuje na to, że jest to zupełnie inny instrument, może cytra (nawiązuje do znaczenia interesującego nas wyrazu w języku staro-cerkiewno-słowiańskim). Przykład: Гусли, мисли мои, песня думка моя. Słownik podaje też derywaty: гуслист, гусляр, гуслистка, гуслярка 'grająсу na tym instrumencie'; гусельник 'rzemieślnik artysta wyrabiający i strojący takie instrumenty'; гуслярить 'grać na takim instrumencie'; гусельничатьй 'podobny do tego instrumentu muzycznego'.

W języku ukraińskim nazwą 'skrzypiec' jest także скрùnкa. Słownik ukraińsko-rosyjski pod redakcją I. M. Kiriczenki (6-tomowy) ${ }^{44}$ tłumaczy ten wyraz poprzez ros. скрѝпка, natomiast $\mathrm{SUM}^{45}$ definiuje go następująco: 'смычковый чотирьохструнный музичний інструмент, найвищий за регістром’ - pol.

\footnotetext{
42 Словарь русского языка, сост. С. И. Ожегов, Москва 1953.

43 В. Даль, Толковный словарь живого великорусского языка, t. I-IV, Москва 1956.

44 Українсько-російський словник, ред. I. М. К и риченко, t. I-VI, Київ 1953-1963.

45 Словник української мови, t. I-XI, Київ 1970-1980 (SUM).
} 
'instrument muzyczny smyczkowy, czterostrunowy o najwyższym rejestrze'. Przykłady: Старий Бабчук грав на скрипиі; Коники один по одному поховали під листочками свої зелені скрипки; В хаті бумкав бубон, бряждали ичимбали, високо і тонко виводила скрипка. Zarówno SUM, jak i słownik pod redakcją Kiriczenki podaje frazeologizm грати першу скрипку. Słownik ukraińsko-rosyjski tłumaczy go poprzez dokładny odpowiednik rosyjski uzpams первую скрипку. Przykład: I в нинішньому році механізатори, як то кажут, гратимуть периу скрипку у вирощуванні качанистої. Słownik ten wymienia też derywat скрипковий 'skrzypcowy', ilustrując go przykładem: Шостакович $\epsilon$ автором 10 симбоній, двох опер, двох балетів, фортепіанного и скрипкового концертів, ряду крупних творів для камерних ансамблів. W słowniku pod redakcją Kiriczenki odnotowano też rzeczownik zỳcra // zỳcri, którego znaczenie oddano przez ros. zýcлu (a więc nie są to skrzypce, lecz jakiś instrument strunowy szarpany, prawdopodobnie lutnia). Przykłady: І гусла знову загули. На гуслі грає, красно співає. Odnotowano też derywaty takie, jak nomen agentis гусля̀ tłumaczone poprzez ros. гусля̀p (SUM definiuje je następująco: 'музыкант, який грає на гуслях, або співець, що акомпонує собі на гуслях' - pol. 'muzyk grający na instrumencie zwanym zycлi lub śpiewak akompaniujący sobie na tym instrumencie'). Przykład: Та ще ц̆ гусляра привела, Якогось чабана Давида. Zamieszczono także adjectivum fundowane przez nomen agentis гусля̀р - гусля̀рний tłumaczone przez ros. гусля̀рный. SUM tłumaczy гуслi następująco: 'старовинний народний багатострунний щипковий музичний інструмент' - pol. 'dawny wielostrunowy szarpany instrument muzyczny (może coś rodzaju harfy lub liry)'. Przykłady: Писані джерела відзначають існування у східних слов'ян струнного музичного інструмента - гусел; Мати грала на скрипиі, на флейті, на гітарі, на гуслях і на фортепіано. Słownik Hrinczenki ${ }^{46}$ podaje dwa znaczenia wyrazu zу̀сла // гу̀слi: 1 . 'odpowiednik ros. гуслu', przykład: $\mathrm{Ha}$ гуслі грає, красно співає; 2. 'skrzypce, ros. скрипка'. Przykłady: Гусла гудуть, до двора йдуть; Гусла загули ... гуляє князь, гуляють гості, ревуть палати на помості. Słownik Hrinczenki notuje też deminutivum гусленьки. Przykład: Та все стиха у гуслоньки грає. Podaje też czasownik гусля̀mu, -ля̀ю 'grać na skrzypcach' - ros. 'играть на скрипке".

Białoruską nazwą 'skrzypiec' jest cкpìınкa. TSBLM ${ }^{47}$ tłumaczy wyraz скры்ıка następująco: 'чатырохструнны смычковы музычны інструмент

46 Словарь украӥнської мови, упор. Б. Грінчен ко, t. I-IV, Київ 1907-1909.

47 Тлумачалны слоўнік беларускай літаратурнай мовы, ред. М. Р. Суднік, Мінск 1999 (TSBLM). 
высокага тэмбру' - pol. 'instrument muzyczny smyczkowy, czterostrunowy o wysokiej skali'. Przykład: Сола на скрыпиьь. TSBLM podaje też frazeologizm першая скрыпка 'pierwsze skrzypce (zarówno w orkiestrze, jak i w znaczeniu przenośnym)'. Zamieszcza też przymiotnik скрыпічны 'skrzypcowy', przykład: Скрыпічны клас oraz zestawienie скрыпічны ключ 'klucz wiolinowy'. TSBLM odnotował także nomen agentis cкрыпàч 'музыкант, які іграє на скрыпцы' - pol. 'skrzypek' oraz nomen agentis rodzaju żeńskiego скрыпа̀чка 'skrzypaczka'. TSBLM odnotował także rzeczownik zỳcлi w znaczeniu 'мнагаструнны шчыпковы музычны інструмент славянскіх народаў' - pol. 'wielostrunowy instrument muzyczny szarpany narodów słowiańskich’. Z definicji tej wynika, że nie jest to nazwa 'skrzypiec', lecz innego instrumentu, może lutni, harfy. Odnotowano także nomen agentis гусля̀р 'музыкант, які іграє на гуслях, а таксама спявак, што акомпанірує сабе на гуслях' - pol. 'muzyk grający na instrumencie zwanym ż̀cri, a także śpiewak akompaniujący sobie na tym instrumencie'. Może chodzi o 'guślarza' (np. z Dziadów Adama Mickiewicza)?

Jak zostało wykazane w artykule, bułgarska nazwa skrzypiec цъигулка jest wyrazem specyficznym dla tego języka, niemającym odpowiedników w pozostałych językach słowiańskich (w serbsko-chorwackim jest jedynie czasownik utworzony od tego rdzenia oraz nomen deverbale). Гъдулка będąca nazwą 'prymitywnych, ludowych skrzypiec' ma swój odpowiednik jedynie w języku macedońskim (гадулка). Nazwa кемане (pochodzenia tureckiego) obecna jest we wszystkich językach Słowian bałkańskich (bułgarski, macedoński, serbsko-chorwacki), a także występuje w innych językach należących do ligi bałkańskiej. Jest więc ona bałkanizmem leksykalnym. Zapożyczenie z języka włoskiego виолина w języku bułgarskim jest wyrazem rzadko używanym, książkowym, natomiast w macedońskim (виолина), serbsko-chorwackim (violína) oraz słoweńskim (violina) jest podstawową nazwą 'skrzypiec'. Гycra są wyrazem ogólnosłowiańskim, przy czym w języku bułgarskim, macedońskim, serbsko-chorwackim, słoweńskim, polskim oznacza on ludowe prymitywne skrzypce (pol. gęśle), natomiast w czeskim, słowackim, górnołużyckim oznacza normalne skrzypce. W języku dolnołużyckim oznacza zarówno 'skrzypce', jak i 'harfę'. W języku rosyjskim i białoruskim wyraz ten oznacza inny instrument muzyczny, należący do grupy strunowych - szarpanych (w białoruskim harfę, w rosyjskim lutnię bądź rodzaj harfy, cytry). W ukraińskim może oznaczać on zarówno 'skrzypce', jak i inny instrument muzyczny (strunowy - szarpany, może lutnię, lirę, harfę). To wschodniosłowiańskie znaczenie jest bliższe pierwotnemu (w najstarszych cyrylo-metodiańskich przekładach Biblii greckie

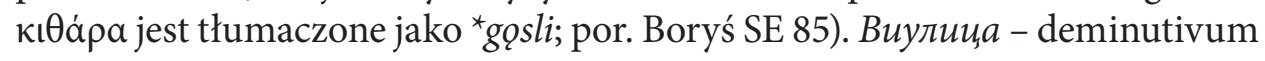


od виола jest w języku bułgarskim dialektyzmem, natomiast nazwa гънилка jest wyrazem izolowanym, odnotowanym jedynie przez Najdena Gerowa. Wyraz rayma w znaczeniu 'skrzypce' występuje w języku bułgarskim jedynie w jednej gwarze (Nowo Seło), w innych dialektach ma on znaczenie 'instrument muzyczny strunowy, podobny do gitary' (prawdopodobnie jest to lutnia).

Nazwy utworzone od czasownika *skripěti // škripati nie są znane w języku bułgarskim ani w ogóle na południu Słowiańszczyzny. Są one charakterystyczne dla języka polskiego (skrzypce) oraz wszystkich języków wschodniosłowiańskich: ros. скри́пка, укр. скри́пка, brus. скри́nка. W językach tych są one podstawową nazwą skrzypiec. Polski wyraz mazanki jest izolowany, oznacza bowiem 'małe ludowe skrzypeczki, spotykane tylko w pewnych regionach Polski, charakteryzujące się bardzo wysokim strojem'.

Wyjątkową nazwą jest połabskie giglia i gigléikia (deminutivum), będące germanizmem (zapożyczenie wprost z języka dolnoniemieckiego).

Podsumowując, trzeba zaznaczyć, iż większość nazw dla 'skrzypiec' w językach słowiańskich jest pochodzenia dźwiękonaśladowczego. Należy do nich bułg. цъигулка, bułg. і mac. гъдулка (гадулка), pol. i wsch-słow. skrzypce (скриіпка, скри́пка, скри́́nка), a także ogólnosłowiańska nazwa, kontynuująca psł. ${ }^{*} g q s l i\left(<^{*} g q d-s l i\right)$ - od czasownika ${ }^{\star} g Q s t i, g q d o$. Bierze się to zapewne stąd, iż instrument ten odgrywa niezwykle ważną rolę w muzyce, zarówno ludowej, jak i poważnej.

\section{Цигулка, гъдулка... and Other Names for 'violin, fiddle' in Bulgarian (in Comparison to Other Slavonic Languages)}

\section{(Summary)}

This paper analyses names for 'violin' in Bulgarian, examined against a Slavonic background. A broader approach has been taken to these names, because the article concerns not only the "classic" violin, but also the folk instruments (fiddles), which have different names in Bulgarian (and other Slavonic languages): ицгулка, гъдулка, гусла, кемане, лаута, виолина, гънилка, виулица. These names are described from the semantic, derivational and etymological point of view. The noun ццгулка, the basic name of 'violin', occurs only in 
Bulgarian and it is unknown in other Slavonic languages, although there are documented derivatives in Serbo-Croatian. The noun кемане 'violin', from Turkish, also occurs in Macedonian and Serbo-Croatian and other languages belonging to the Balkan league. The second part of the papers is devoted to the names for 'violin' in other Slavonic languages. Some names, extant only in some of the Slavonic languages, are derived from an onomatopoeic stem (Bulg. иигулка, Pol. skrzypсе, East-Slavonic скрипка). Most of the Slavonic languages have a noun derived from gosli, a Common Slavic ancestor, but in some Slavonic languages (Czech, Slovak, and Sorabic) this word now means the classic violin, while in others it means 'fiddle' (comp. Pol. geśle, Bulg. гусла), and in the Eastern Slavonic languages and Old Church Slavonic it means a 'plucked string instrument' 'a kind of lute'. In Serbo-Croatian it means both the classic violin and primitive fiddle. Polabian has its own name form 'violin' gigléikia, which comes from German. 